\title{
CORRECTIONS
}

\section{The future of the NHS-irreversible privatisation?}

In this Observations article (an edited transcript of a video interview by Jill Mountford with Dr Lucy Reynolds on 3 March 2013), Jill Mountford wishes us to clarify that it was as a member of the steering committee on the "Save Lewisham
Hospital" campaign that she conducted the interview (BMJ 2013;346:f1848, doi:10.1136/bmj.f1848).

Cite this as: BMJ 2013;346:f2047

๑ BMJ Publishing Group Ltd 2013 